\title{
Determinan Kepuasan, Kepercayaan dan Loyalitas Pelanggan UKM Sasirangan Melalui Media Sosial Instagram (Studi Pada Pelanggan yang merupakan Followers/Pengikut Kasasiur_Banjar )
}

\author{
Rizki Adhani Fadila ${ }^{1}$, RR Yulianti Prihatiningrum ${ }^{2}$ \\ ${ }^{1,2}$ Universitas Lambung Mangkurat \\ Email: rizky0886@gmail.com
}

\begin{abstract}
This study aims to analyze the effect of user interface quality, information quality, privacy perception and price on satisfaction, analyze the influence of user interface quality, information quality, privacy perception and satisfaction on trust and analyze the influence of satisfaction and trust on customer loyalty.

This research is a quantitative study using a survey approach. This research method uses a questionnaire with 150 respondents who are Instagram followers with kasasiur_banjar accounts. In this study using the Non Probability Sampling technique by purposive sampling. Measurement of variables using a Likert scale technique with a scale of weights from 1 to 5. To determine the effect of the studied variables Structural Equation Modeling (SEM) analysis tools are used.

The results of the study concluded that User Interface quality has a significant positive effect on customer satisfaction. User Interface quality has a significant positive effect on customer trust. Information quality has a significant positive effect on customer satisfaction. The quality of information $t$ has a significant positive effect on customer trust. Privacy perception has a significant positive effect on customer satisfaction. Privacy perception has a significant positive effect on customer trust. Price has a significant positive effect on customer satisfaction. Customer satisfaction has a significant positive effect on trust. Customer satisfaction has a significant positive effect on customer loyalty. Customer trust has a significant positive effect on customer loyalty.
\end{abstract}

Keywords: User Interface Quality, Information Quality, Privacy Perception, Price, Satisfaction, Trust and Customer Loyalty.

Abstrak

Penelitian ini bertujuan untuk menganalisis user interface quality, kualitas informasi, persepsi privasi dan harga terhadap kepuasan, menganalisa pengaruh user interface quality, kualitas informasi, persepsi privasi dan kepuasan terhadap kepercayaan serta menganalisa pengaruh kepuasan dan kepercayaan terhadap loyalitas pelanggan.

Penelitian ini merupakan penelitian kuantitatif dengan menggunakan pendekatan survey. Metode penelitian ini menggunakan kuesioner dengan 150 responden yang merupakan followers (pengikut) instagram dengan akun kasasiur_banjar. Pada penelitian ini menggunakan teknik Non Probability Sampling dengan cara Sampling Purposive. Pengukuran variabel menggunakan tehnik skala Likert dengan skala bobot dari 1 sampai 5. Untuk mengetahui pengaruh dari variabel yang diteliti digunakan alat analisis Structural Equation Modeling (SEM).

Hasil penelitian menyimpulkan bahwa User Interface quality memiliki pengaruh positif signifikan terhadap kepuasan pelanggan. User Interface quality memiliki pengaruh positif signifikan terhadap kepercayaan pelanggan. Kualitas informasi memiliki pengaruh positif signifikan terhadap kepuasan pelanggan. Kualitas informasi $t$ memiliki pengaruh positif signifikan terhadap kepercayaan pelanggan. Persepsi privasi memiliki pengaruh positif signifikan terhadap kepuasan pelanggan. Persepsi privasi memiliki pengaruh positif signifikan terhadap kepercayaan pelanggan. Harga memiliki pengaruh positif signifikan terhadap kepuasan pelanggan. Kepuasan pelanggan memiliki pengaruh positif signifikan terhadap kepercayaan. Kepuasan pelanggan memiliki pengaruh positif signifikan terhadap loyalitas pelanggan. Kepercayaan pelanggan memiliki pengaruh positif signifikan terhadap loyalitas pelanggan.

Kata Kunci: User Interface Quality, Kualitas Informasi, Persepsi Privasi, Harga, Kepuasan, Kepercayaan dan Loyalitas Pelanggan.

(C) 2021 Jurnal Riset Inspirasi Manajemen dan Kewirausahaan 


\section{PENDAHULUAN}

Kemajuan yang sangat pesat dalam dunia teknologi informasi menuntut para pelaku usaha untuk dapat memahami serta memanfaatkannya dalam kegiatan bisnis sebagai upaya untuk meningkatkan daya saing. Jumlah pemakai internet meningkat secara drastis setiap tahunnya, serta perilaku konsumen yang menginginkan informasi cepat dan transaksi yang dapat dilakukan selama 24 jam, dianggap menjadi faktor pendorong berkembangnya bisnis berbasis teknologi informasi (Khristianto, 2011). Jumlah pengguna internet Indonesia yang meningkat pesat membawa dampak positif bagi peluang bisnis online.

Salah satu aplikasi media sosial yang popular adalah Instagram. Instagram banyak digunakan oleh para pelaku usaha untuk menerapkan strategi paling efektif dan efisien dalam bisnis dan pemasaran. Instagram merupakan salah satu media sosial yang populer bagi masyarakat Indonesia. Data dari dunia.com menampilkan survei yang dilakukan oleh JakPat, bahwa lebih dari setengah pengguna Instagram di Indonesia mengikuti akun online shop. Dari hasil survei tersebut, sebanyak $56,2 \%$ responden mengatakan "Ya" saat ditanya apakah mereka mengikuti akuntoko online di Instagram, sebagian besar dari mereka mengikuti akun toko onlineyang berjualan pakaian dan aksesorisnya. Data lengkap yang hasil survey yang dilakukan oleh Jakpat yang diambil dari dunia.com dapat dilihat pada gambar berikut:

Instagram Users Ages 18-35 in Indonesia Who Follow Digital Retailers on Instagram, by Type, Jan 2016

$\%$ of respondents

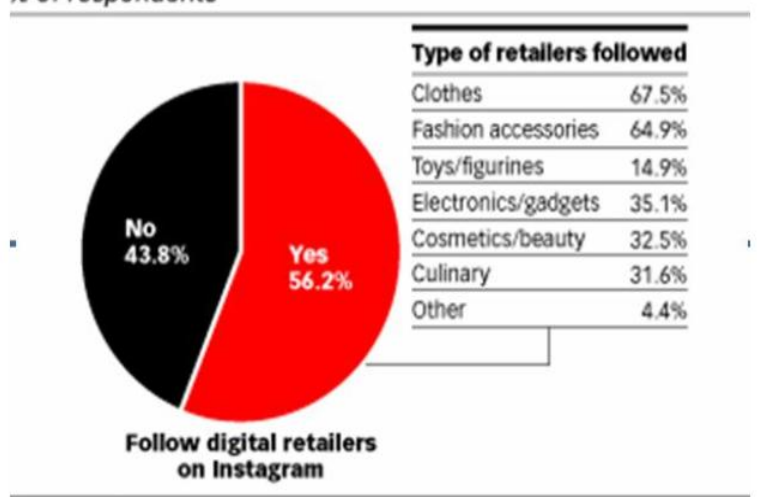

Note: $n=203$

Source: lakPat, "Food Buyer on Instagram," Feb 3, 2016

205168

wwwe Marketer con

Hal ini menarik perhatian pelaku Usaha Kecil dan Menengah (UKM) untuk menggunakan media online melalui media sosial Instagram guna mempromosikan hasil karyanya. Media sosial memudahkan para pelaku bisnis untuk mengumpulkan pelanggan yang lebih luas. Media sosial jika digunakan dengan tepat, dapat memberikan dampak pemasaran yang menguntungkan.

Ada beberapa faktor menjadi permasalahan yang sering dialami oleh pengguna instagram yaitu tampilan instagram (User Interface Quality) yang memperlihatkan produk yang dijual; kurangnya informasi yang dapat diberikan tentang sebuah produk yang ditampilkan di instagram, sehingga dapat mempengaruhi pengguna instagram dalam mempercayai dan bahkan membeli produk tersebut; faktor keamanan privasi bagi pelanggan juga menjadi salah satu faktor yang dapat mempengaruhi kepuasan dan kepercayaan, karena pelanggan akan merasa aman apabila privasi dirinya dapat terlindungi tidak tersebar kepada pelanggan yang lain;Informasi harga yang dicantumkan didalam informasi foto yang dimuat di instagram juga dapat mempengaruhi kepuasaan dan kepercayaan pengguna instagram untuk melakukan pembelian; serta faktor kepercayaan dan kepuasaan yang didapat dari beberapa faktor yang dapat mempengaruhinya tersebut, dapat pula mempengaruhi keinginan untuk terus melakukan transaksi pembelian suatu produk yang dianggap menarik oleh pengguna instagram (Eid, MI, 2011; Dhiranty et al., 2017; Brilliant dan Achyar, 2013; Hasniaty, 2015).

Para UKM melalui media sosial Instagram harus bisa membuat konsumen menerima informasi dan menarik minat konsumen untuk mau membeli/belanja produk buatannya secara online. Pada penelitian ini, UKM Kalimantan Selatan yang akan menjadi fokus penelitian adalah UKM Produk Sasirangan yang menggunakan media sosial instagram untuk memasarkan produk buatannya. Salah satu UKM sasirangan yang menggunakan instagram sebagai sarana untuk memasarkan produk nya adalah Kasasiur Banjar Sasirangan dengan akun instagram "kasasiur_banjar". Kasasiur Banjar Sasirangan setelah menggunakan media instagram membuat namadan produknya semakin dikenal masyarakat. Melalui media instagram ini pula banyak pesanan dari luar Provinsi Kalimantan Selatan seperti dari Aceh, Sumatra Utara, Sulawesi Selatan, Jakarta dan DIY Jogyakarta.

Meskipun mengalami peningkatan baik pendapatan maupun jumlah pelanggan, Kasasiur Banjar juga menerima komplain dari pelanggan. Komplain dari pelanggan yang sering dialami adalah dari segi warna, tidak sesuai dengan foto yang ditampilkan pada instagram. Kasasiur Banjar menjelaskan bahwa untuk pewarnaan agak sulit untuk menjelaskannya, tetapi pada foto yang ditampilkan pada instagram selalu diberikan 
informasi bahwa warna dapat berbeda dengan aslinya karena pengaruh kamera foto, proses editing dan layar masing-masing Smartphone.

Beberapa penelitian terdahulu telah meneliti tentang variabel-variabel yang dibuat dalam penelitian ini seperti penelitian Eid, MI (2011) dan Dhiranty et al.(2017) yang mengungkapkan bahwa User Interface qualityberpengaruh terhadap kepuasan dan kepercayaan pelanggan. Berbeda dengan penelitian Brilliant dan Achyar (2013) yang menyatakan bahwa User Interface quality tidak berpengaruh terhadap kepuasan dan kepercayaan pelanggan.

Penelitian Dhiranty et al. (2017) mengungkapkan bahwa kualitas informasi mempengaruhi faktor kepuasaan dan kepercayaan pelanggan. Berbeda dengan penelitian Eid, MI (2011) yang menyatakan bahwa kualitas informasi mempengaruhi kepuasan tetapi tidak berpengaruh terhadap kepercayaan. Berbeda lagi dengan penelitian Brilliant dan Achyar (2013) yang menyatakan bahwa kualitas informasi tidak berpengaruh terhadap kepuasaan dan kepercayaan pelanggan.

Penelitian Dhiranty et al. (2017) menyatakan bahwa persepsi privasi berpengaruh terhadap kepuasan dan kepercayaan pelanggan. Hal ini berbeda dengan penelitian yang dilakukan oleh Brilliant dan Achyar (2013) yang menyatakan persepsi privasi tidak berpengaruh terhadap kepuasan dan kepercayaan pelanggan. Tetapi berbeda lagi dengan penelitian yang telah dilakukan oleh Eid, MI (2011), yang menyatakan bahwa persepsi privasi berpengaruh terhadap kepercayaan pelanggan tetapi tidak berpengaruh terhadap kepuasan pelanggan.

Penelitian Hasniaty (2015) menyatakan bahwa harga berpengaruh positif signifikan terhadap kepercayaan dan kepuasan, tetapi tidak berpengaruh pada loyalitas pelanggan. Kepercayaan dan kepuasan pelanggan berpengaruh positif terhadap loyalitas pelanggan. Hal ini berbeda dengan penelitian yang dilakukan Hidayat (2014) yaitu menyatakan harga tidak berpengaruh terhadap kepuasaan dan kepercayaan sehingga menyebabkan harga berpengaruh negatif dan signifikan terhadap loyalitas pelanggan. Berbeda lagi dengan penelitian yang dilakukan oleh Wulandari dkk(2016) yang menyatakan harga menjadi variabel yang paling mendominasi dalam mempengaruhi loyalitas pelanggan, dengan harga yang kompetitif maka pelanggan akan selalu loyal dengan asumsi pelanggan tidak akan mendapatkan harga yang lebih baik sekalipun mendapatkan harga yang lebih murah.

Menurut penelitian Dhiranty et al.(2017) yang mengungkapkan bahwa kepuasaan memiliki pengaruh terhadap kepercayaan yaitu semakin tinggi kepuasaan pelanggan maka semakin tinggi pula tingkat kepercayaannya. Jika dilihat dari nilai signifikan, kepuasan tidak selalu mendorong pelanggan untuk loyal (setia), tetapi variabel kepercayaan memiliki nilai yang signifikan terhadap loyalitas. Artinya, semakin tinggi tingkat kepercayaan maka cenderung akan membuat pelanggan menjadi loyal.

Variabel-variabel User Interface quality, kualitas informasi, persepsi privasi, harga, kepuasan, kepercayaan dan loyalitas diambil dikarenakan terdapat perbedaan pada penelitianpenelitian terdahulu. Sehingga fokus penelitian ini adalah menguji dan menganalisis pengaruh User Interface quality, kualitas informasi, persepsi privasi, harga, kepuasan, dan kepercayaan terhadap loyalitas pelanggan, dengan fokus penelitian yaitu Followers (pengikut) kasasiur_banjar di media sosial Instagram.

\section{KAJIAN LITERATUR}

User Interface Quality didefinisikan sebagai fungsi teknis situs dan desainnya, serta saluran interaksi antara konsumen dan penyedia layanan elektronik (Gummerus, Johanna et al., 2004). Menurut Park, CH \& Kim, YG, (2003) User Interface quality mempengaruhi kepuasan pelanggan secara langsung, karena memberikan bukti fisik dari kompetensi penyedia layanan serta memfasilitasi penggunaan layanan yang mudah. User Interface quality juga dapat mempengaruhi kepercayaan secara langsung serta kemudahan navigasi, desain antarmuka, dan panduan pengguna mempengaruhi pembentukan kepercayaan konsumen (Gummerus, Johanna et al., 2004).

Kualitas Informasi didefinisikan sebagai persepsi pelanggan terhadap kualitas informasi tentang produk yang disediakan oleh situs online sehingga sangat memberikan pengaruh langsung terhadap kepuasan pelanggan (Park dan Kim 2003). Kualitas informasi produk didefinisikan sebagai persepsi pelanggan terhadap kualitas informasi tentang produk yang disediakan oleh situs online sehingga sangat memberikan pengaruh langsung terhadap kepercayaan pelanggan (Park dan Kim 2003).

Persepsi Privasi menurut Flavianus dan Guinalíu (2006) mengacu pada jaminan teknis yang memastikan bahwa persyaratan hukum dan praktik yang baik terkait privasi akan dipenuhi secara efektif. Misalnya, perusahaan dapat berjanji bahwa data tidak akan diberikan kepada pihak ketiga tanpa persetujuan pelanggan, hal ini dapat menimbulkan kepuasan kepuasan pelanggan terhadap perusahaan tersebut. Namun, peretas mungkin mendapatkan data dan menyerahkannya kepada pelaku. Invasi privasi inihanya dapat dicegah dengan 
menggunakan langkah-langkah keamanan yang sesuai. Flavianus dan Guinalíu (2006) juga menyatakan bahwa kepercayaan pada sebuah situs online yang sangat dipengaruhi oleh keamanan yang dirasakan penanganan data pribadi, karena keamanan adalah isu yang paling signifikan dalam e-commerce, dan itu sangat penting dalam membangun kepercayaan.

Harga merupakan faktor yang sangat penting dalam kepuasan pelanggan, karena pelanggan akan memikirkan masalah harga apabila sedang mengevaluasi nilai dari suatu barang yang diterima (Hidayat 2014). Kaitan antara harga dan kepuasan pelanggan juga telah dikemukan oleh Hasniaty (2015) dan Shartykarini, S (2016) yang didalam penelitiannya dikemukan bahwa harga yang terjangkau dapat memberikan kepuasan konsumen, dan disimpulkan bahwa harga berpengaruh positif pada kepuasan konsumen.

Kepuasan konsumen menurut Kotler dan Keller (2009) adalah perasaan senang atau kecewa seseorang yang timbul karena membandingkan kinerja yang dipersepsikan produk (hasil) terhadap ekspektasi mereka. Jika kinerja sesuai ekspektasi, pelanggan akan puas. Jika kinerja tidak sesuai dengan ekspektasi, pelanggan tidak puas. Jika kinerja melebihi ekspektasi, pelanggan akan sangat puas atau senang. Pelanggan yang sangat puas umumnya lebih lama setia (loyalitas) dan membeli lebih banyak ketika perusahaan memperkenalkan produk baru dan meningkatkan produksi yang ada.

Perusahaan ingin memenangkan persaingan dalam bisnis online dapat memberikan perhatian penuh pada kepuasan pelanggan. Perhatian penuh pada kepuasan pelanggan akan memberikan dampak positif terhadap perusahaan. Pelanggan yang merasa puas saat berbelanja akan membentuk suatu kepercayaan pelanggan untuk berbelanja sehingga pelanggan akan merasa terdorong untuk melakukan pembelian ulang pada perusahaan tersebut (Norhermaya dan Soesanto, 2016).

Kepercayaan menurut Gunawan (2013) merupakan bentuk sikap yang menunjukkan perasaan suka dan tetap bertahan untuk menggunakan suatu produk atau merek (loyalitas). Kepercayaan akan timbul dari pikiran konsumen apabila produk yang dibeli mampu memberikan manfaat atau nilai yang diinginkan konsumen pada suatu produk.

Loyalitas menurut Kotler dan Keller (2009:138) adalah komitmen yang dipegang secara mendalam untuk membeli atau mendukung kembali produk atau jasa yang disukai di masa depan meski pengaruh situasi dan usaha pemasaran berpotensi menyebabkan pelanggan beralih. Loyalitas pelanggan adalah komitmen untuk menggunakan barang atau jasa dimasa depan. Dalam e-commerce, loyalitas adalah niat konsumen untuk membeli dari sebuah situs web e-commerce dan niat untuk tidak beralih ke situs-situs lain yang menawarkan hal yang sama (Brilliant \&Achyar, 2013).

\section{Kerangka Konseptual}

Berdasarkan penelitian terdahulu serta teori maka dikembangkan menjadi sebuah kerangka konseptual dapat terlihat pada gambar berikut:

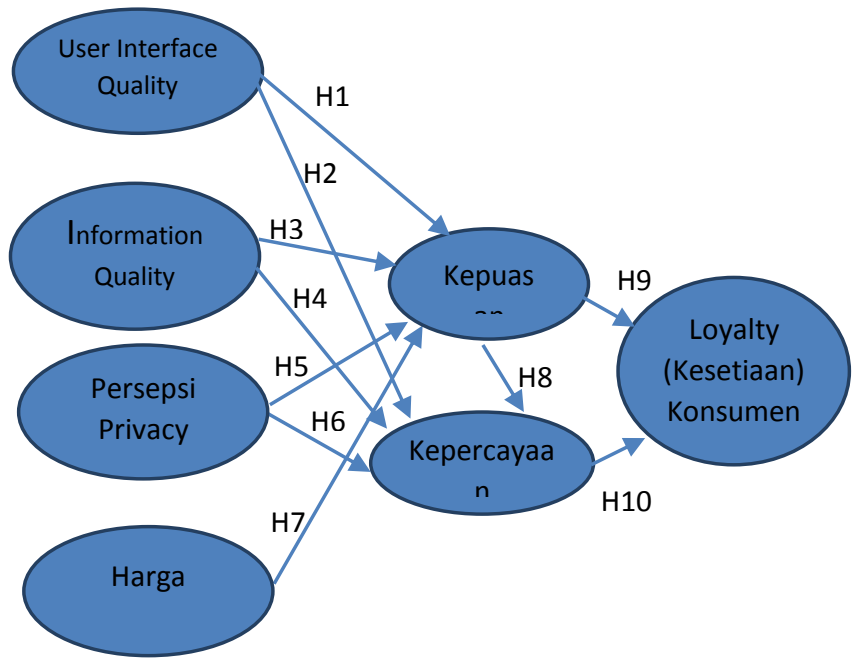

Gambar 1: Kerangka Konseptual

Sumber : Eid, MI (2011); Dhirantyet al. (2017) dan Hasniaty (2015) dikembangkan untuk penelitian ini (2019)

\section{Hipotesis Penelitian}

Berdasarkan kerangka konseptual dan teori pendukung maka peneliti mengajukan hipotesis sebagai berikut :

User Interface quality mempengaruhi kepuasan pelanggan secara langsung, karena memberikan bukti fisik dari kompetensi penyedia layanan serta memfasilitasi penggunaan layanan yang mudah. Hal ini juga diperkuat dengan hasil penelitian yang dilakukan Eid, MI (2011) dan Dhiranty et al. (2017) yang menyatakan bahwa user interface quality memiliki pengaruh positif pada kepuasan konsumen. Maka dari itu hipotesis yang dapat dirumuskan adalah sebagai berikut:

\section{H1: User Interface Quality mempengaruhi kepuasaan.}

User Interface quality juga dapat mempengaruhi kepercayaan secara langsung serta kemudahan navigasi, desain antar muka, dan panduan pengguna mempengaruhi pembentukan kepercayaan konsumen (Gummerus, Johanna et al., 2004). Hal ini juga diperkuat dengan hasil penelitian yang dilakukan Eid, MI (2011) dan Dhiranty et al. (2017) yang menyatakan bahwa user interface quality memiliki pengaruh positif pada kepercayaan konsumen. Maka dari itu hipotesis yang dapat dirumuskan adalah sebagai berikut: 


\section{H2: User Interface Quality mempengaruhi} kepercayaan.

Kualitas Informasi didefinisikan sebagai persepsi pelanggan terhadap kualitas informasi tentang produk yang disediakan oleh situs online sehingga sangat memberikan pengaruh langsung terhadap kepuasan pelanggan (Park dan Kim 2003). Hal ini juga diperkuat dengan hasil penelitian yang dilakukan oleh Eid, MI (2011) dan Dhiranty et al. (2017) yang menyatakan bahwa kualitas informasi memiliki pengaruh positif pada kepuasan konsumen. Maka dari itu hipotesis yang dirumuskan adalah:

\section{H3: Kualitas informasi mempengaruhi kepuasaan. \\ Kualitas informasi produk didefinisikan} sebagai persepsi pelanggan terhadap kualitas informasi tentang produk yang disediakan oleh situs online sehingga sangat memberikan pengaruh langsung terhadap kepercayaan pelanggan (Park dan Kim 2003). Hal ini juga diperkuat dengan hasil penelitian yang dilakukan oleh Dhiranty et al.(2017) dan Brilliant \& Achyar (2013) yang menyatakan bahwa kualitas informasi memiliki pengaruh positif pada kepercayaan konsumen. Maka dari itu hipotesis yang dapat dirumuskan adalah sebagai berikut:

\section{H4: Kualitas informasi mempengaruhi kepercayaan.}

Persepsi Privasi menurut Flavianus dan Guinalíu (2006) mengacu pada jaminan teknis yang memastikan bahwa persyaratan hukum dan praktik yang baik terkait privasi akan dipenuhi secara efektif. Misalnya, perusahaan dapat berjanji bahwa data tidak akan diberikan kepada pihak ketiga tanpa persetujuan pelanggan, hal ini dapat menimbulkan kepuasan kepuasan pelanggan terhadap perusahaan tersebut. Namun, peretas mungkin mendapatkan data dan menyerahkannya kepada pelaku. Invasi privasi inihanya dapat dicegah dengan menggunakan langkah-langkah keamanan yang sesuai.Hal ini juga diperkuat dengan hasil penelitian yang dilakukan oleh Dhiranty et al. (2017) yang menyatakan bahwa persepsi privasi memiliki pengaruh positif pada kepuasan konsumen. Maka hipotesis yang dapat dirumuskan adalah:

H5: Persepsi privasi mempengaruhi kepuasan.

Kekhawatiran tentang kepercayaan akan data pribadi ketika melakukan bisnis online telah diidentifikasi sebagai hambatan yang signifikan terhadap bisnis online dan pertumbuhan ekonomi (Brendon, 2002). Flavianus dan Guinalíu (2006) juga menyatakan bahwa kepercayaan pada sebuah situs online yang sangat dipengaruhi oleh keamanan yang dirasakan penanganan data pribadi, karena keamanan adalah isu yang paling signifikan dalam e-commerce, dan itu sangat penting dalam membangun kepercayaan. Kaitan antara persepsi keamanan dan kepercayaan juga telah dikemukakan oleh Eid, MI (2011) dan Dhiranty et al. (2017) yang didalam penelitiannya dikemukakan bahwa persepsi privasi memiliki pengaruh positif pada kepercayaan konsumen. Maka hipotesis yang dapat dirumuskan adalah:

\section{H6: Persepsi privasi mempengaruhi kepercayaan.}

Harga merupakan faktor yang sangat penting dalam kepuasan pelanggan, karena pelanggan akan memikirkan masalah harga apabila sedang mengevaluasi nilai dari suatu barang yang diterima (Hidayat 2014). Kaitan antara harga dan kepuasan pelanggan juga telah dikemukan oleh Hasniaty (2015) dan Shartykarini, S (2016) yang didalam penelitiannya dikemukan bahwa harga yang terjangkau dapat memberikan kepuasan konsumen, dan disimpulkan bahwa harga berpengaruh positif pada kepuasan konsumen. Maka hipotesis yang dapat dirumuskan adalah:

\section{H7: Harga mempengaruhi kepuasan.}

Perusahaan ingin memenangkan persaingan dalam bisnis online dapat memberikan perhatian penuh pada kepuasan pelanggan. Perhatian penuh pada kepuasan pelanggan akan memberikan dampak positif terhadap perusahaan. Pelanggan yang merasa puas saat berbelanja akan membentuk suatu kepercayaan pelanggan untuk berbelanja sehingga pelanggan akan merasa terdorong untuk melakukan pembelian ulang pada perusahaan tersebut (Norhermaya dan Soesanto, 2016). Hal ini juga sesuai dengan hasil penelitian yang dilakukan oleh Dhiranty et al (2017) yang menyatakan bahwa kepuasaan mempunyai pengaruh terhadap kepercayaan. Berdasarkan peneliti tersebut maka peneliti mengajukan hipotesis sebagai berikut:

\section{H8 : Kepuasan mempengaruhi kepercayaan}

Kotler dan Keller (2009) menyatakan kepuasan konsumen adalah perasaan senang atau kecewa seseorang yang timbul karena membandingkan kinerja yang dipersepsikan produk (hasil) terhadap ekspektasi mereka. Jika kinerja sesuai ekspektasi, pelanggan akan puas. Jika kinerja tidak sesuai dengan ekspektasi, pelanggan tidak puas. Jika kinerja melebihi ekspektasi, pelanggan akan sangat puas atau senang.Pelanggan yang sangat puas umumnya lebih lama setia (loyalitas) dan membeli lebih banyak ketika perusahaan memperkenalkan produk baru dan meningkatkan produksi yang ada.Hal ini sesuai dengan hasil penelitian yang dilakukan oleh Eid, MI (2011), Wulandari dkk (2016) dan Hidayat, DR (2014) menyatakan bahwa kepuasaan positif mempengaruhi loyalitas pelanggan. Berdasarkan peneliti tersebut maka peneliti mengajukan hipotesis sebagai berikut: 


\section{H9 : Kepuasan mempengaruhi loyalty pelanggan \\ Gunawan (2013) menyatakan kepercayaan} sebagai bentuk sikap yang menunjukkan perasaan suka dan tetap bertahan untuk menggunakan suatu produk atau merek (loyalitas). Kepercayaan akan timbul dari pikiran konsumen apabila produk yang dibeli mampu memberikan manfaat atau nilai yang diinginkan konsumen pada suatu produk. Hal ini sesuai dengan hasil penelitian yang dilakukan Dhiranty et al (2017), Brilliant \& Achyar (2013) dan Hasniaty (2015)yang menyatakan bahwa kepercayaan positif mempengaruhi loyalitas pelanggan. Berdasarkan peneliti tersebut maka peneliti mengajukan hipotesis sebagai berikut:

\section{H10:Kepercayaan mempengaruhi loyalitasy pelanggan}

\section{METODE PENELITIAN}

Penelitian ini menggunakan metode penelitian kuantitatif dengan jenis penelitiannya adalah penelitian survey untuk mendapatkan data. Penelitian ini dilakukan di Indonesia melalui akun instagram kasasiur_banjar yaitu pada individu, yaitu followers (pengikut) Usaha Kecil Menengah (UKM) Sasirangan binaan Dinas Perdagangan Provinsi Kalimantan Selatan Kasasiur banjar sasirangan yang merupakan pada pengguna media sosial instagramdengan akunkasasiur_banjar. Populasi dalam penelitian ini adalah pelanggan yang menjadi pelanggan UKM Kasasiur Banjar Sasirangan yang merupakan followers (pengikut) instagram dengan akun kasasiur_banjar. Dengan jumlah indicator penelitian sebanyak 27 indikator maka berdasar pendapat Ferdinand (2006:58) jumlah sampel yang diambil adalah jumlah indikator dikalikan 5-10 sehingga range sampel pada penelitian ini adalah 135 s/d 270 sampel. Berdasarkan pedoman ukuran sampel diatas, maka penelitian ini akan mengambil 150 responden dengan menggunakan tehnik purposive sampling dengan criteria bahwa responden merupakan followers (pengikut) instagram kasasiur_banjar, berusia minimal 17 tahun dan pernah melakukan pembelian minimal 2 kali.

Penelitian ini mempunyai dua jenis variabel yaitu variabel eksogen dan variabel endogen. Variabel eksogen meliputi User Interface Quality, Kualitas informasi, Persepsi Privasi dan Harga. Variabel endogen dalam penelitian ini adalah kepuasan, kepercayaan dan loyalitas pelanggan.

User Interface Quality adalah tampilan Instagram baik secara visual atau kasat mata atau melalui foto yang ditampilkan dan searchbility. Tampilan pada Instagram secara kasat mata dapat membuat pelanggan tertarik dan untuk foto yang ditampilkan merupakan foto yang yang menggambarkan bagaimana desain sasirangan sehingga dapat membuat pelanggan tertarik dan akhirnya akan melakukan pembelian. Untuk searchbility adalah kemudahan konsumen dalam mencari akun UKM tersebut pada media sosial instagram. Menurut Eid, MI (2011) indikator User Interface Quality meliputi tampilan pada Instagram merupakan tampilan yang menarik, desain yang ditampilkan melalui foto merupakan design yang menarik dan akun instagram UKM mudah dicari oleh pelanggan.

Kualitas Informasi (Information Quality) informasi produk yang diberikan oleh UKM Sasirangan melalui unggahan foto pada instagram miliknya, menyebutkan informasi tentang produk seperti bahan, ukuran dan motif produk yang ditampilkan pada instagram tersebut. Indikator dari kualitas informasi menurut Eid, MI (2011) meliputi menyebutkan jenis bahan produk sasirangan pada foto yang ditampilkan, menyebutkan ukuran produk sasirangan pada foto yang ditampilkan, menyebutkan nama motif sasirangan pada foto yang ditampilkan dan memberikan informasi yang terbaru tentang produk yang ditampilkan.

Perespsi Privasi memberikan gambaran bahwa pelanggan yang menjadi followers (pengikut) instagram UKM Sasirangan akan merasa aman dalam hal informasi pribadinya dan akan merasa yakin akan UKM tersebut. Karena pelanggan akan merasa aman apabila privasi dirinya dapat terlindungi tidak tersebar kepada pelanggan yang lain, karena bagaimana pelanggan yang menjadi pengikut (followers) instagram UKM Sasirangan akan merasa informasi pribadinya atau privasinya dapat terjaga. Indikator dari Persepsi Privasi menurut Eid, MI (2011) meliputi Pe Perasaan aman berbagi informasi data pribadi pelanggan kepada UKM Sasirangan, Keyakinan bahwa UKM Sasirangan tidak akan menyebarkan informasi pribadi kepada orang lain tanpa sepengetahuan pelanggan, UKM sasirangan menggunakan data pribadi pelanggan hanya untuk keperluan aktivitas pembelian saja dan UKM Sasirangan menunjukkan kepedulian terhadap privasi pelanggannya.

Harga adalah harga produk yang tercantum pada foto yang ditampilkan pada Instagram yang dapat dilihat dan diketahui konsumen sehingga variabel harga penting dalam hal mempengaruhi kepuasan konsumen setelah melakukan pembelian untuk produk tersebut. Dari Harga tersebut juga dapat di nilai sesuai dengan kualitasnya dan dapat bersaing dengan UKM sasirangan yang lain. Indikator dari Harga menurut Hasniaty (2015) meliputi Harga produk sasirangan yang ditampilkan jelas, Harga produk sasirangan yang ditampilkan dapat dimengerti, Harga produk sasirangan sesuai dengan kualitas produk yang telah ditampilkan dan 
Harga produk sasirangan dapat bersaing dengan pesaing lainnya.

Kepuasan dalam penelitian adalah bagaimana kebutuhan, keinginan dan harapan konsumen/ pelanggan yang menjadi pengikut (followers) instagram UKM Sasirangan terpenuhi sehingga dapat mempengaruhi loyalitas konsumen terhadap produk tersebut. Indikator dari Kepuasan diadaptasi dari Kotler dan Keller (2009) dan Eid, MI (2011) meliputi Terpenuhinya kebutuhan pelanggan yang merupakan followers (pengikut) instagram UKM Sasirangan, Terpenuhinya keinginan pelanggan yang merupakan followers (pengikut) instagram UKM Sasirangan, Terpenuhinya harapan pelanggan yang merupakan followers (pengikut) instagram UKM Sasirangan dan Pelanggan akan membicarakan hal-hal yang menyenangkan tentang produk UKM Sasirangan.

Kepercayaan dalam penelitian ini menunjukkan konsumen percaya dan menjadi pengikut (followers) instagram UKM Sasirangan dan akan meluangkan waktu untuk melihat instagram tersebut serta membelinya. Dari hal tersebut akan terlihat kepercayaan konsumen yang nantinya akan mempengaruhi loyalitas konsumen terhadap UKM Sasirangan. Indikator dari kepercayaandiadaptasi dari Kotler dan Keller (2009) dan Dhiranty et al. (2017) yaitu Kepercayaan pelanggan yang merupakan Followers (pengikut) terhadap akun instagram UKM Sasirangan, Kepercayaan yang muncul karena banyak Followers (pengikut) yang mengikuti akun UKM sasirangan, Pelanggan akan meluangkan waktu untuk melihat akun instagram UKM Sasirangan dan Pelanggan akan membeli lebih banyak ketika UKM Sasirangan mengeluarkan produk baru.

Loyalitas adalah keinginan untuk mengunjungi situs lebih sering dan mempertahankan pembelian (Dhiranty et al., 2017). Didalam variabel loyalitas konsumen ini akan terlihat kesetiaan konsumen memilih UKM tersebut serta akan membeli kembali produk sasirangan kepada UKM Sasirangan dan akan merekomendasikan kepada orang lain. Indikator dari variabel loyalitas diadaptasi dari Eid, MI (2011) yaitu berencana melakukan pembelian ulang, akan merekomendasikan produk sasirangan kepada orang lain, setia karena telah UKM Sasirangan telah memberikan kepuasan dan setia karena telah UKM Sasirangan telah memberikan kepercayaan

Untuk mengukur variabel dalam penelitian ini menggunakan skala Likert dengan rentang skor mulai 1 (sangat tidak setuju), 2 (tidak setuju), 3 (ragu-ragu), 4 (setuju) dan 5 (sangat tidak setuju). Instrument penelitian menggunakan kuesioner. Guna memiliki instrument penelitian yang dapat diandalkan kemampuannya maka dilakukan uji validitas dengan menggunakan uji korelasi product moment dan reliabilitas dengan menggunakan metode Alpha Croncbach.

Tehnik analisis yang digunakan yaitu Structural Equation Modeling (SEM). Teknik SEM memungkinkan seorang peneliti menguji beberapa variabel dependen sekaligus, dengan beberapa variabel independen. Dalam permodelan SEM, variabel-variabel laten yang digunakan dalam model dibedakan juga sebagai variabel laten eksogen dan variabel laten endogen. Variabel Laten eksogen adalah sinonim dengan variabel independen yaitu variabel yang mempengaruhi nilai dari variabel lain dalam model. Variabel laten endogen adalah sinonim dengan variabel dependen yaitu dipengaruhi oleh variabel eksogen dalam model tersebut baik secara langsung maupun tidak langsung (Ferdinand, 2006:5).

Pengoperasian SEM sendiri menggunakan paket software statistic AMOS. SEM adalah penggabungan antara dua konsep statistika, yaitu konsep analisis faktor yang masuk pada model pengukuran (Structural Model). Model pengukuran menjelaskan hubungan antara variabel dengan indicator-indikatornya dan model struktural menjelaskan hubungan antar variabel. Kelebihan aplikasi SEM dalam penelitian manajemen adalah kemampuan untuk mengkonfirmasi dimensidimensi dari sebuah konsep atau faktor serta kemampuannya untuk mengukur pengaruh hubungan-hubungan secara teoritis. Dalam SEM ada beberapa indeks kesesuaian dan cut off value yang digunakan untuk menguji apakah sebuah model dapat diterima atau ditolak, yaitu:

1. $\mathrm{X}^{2}$-Chi Square Statistic

Uji chi square sangat bergantung pada besarnya sampel yang digunakan dalam penelitian, karena model yang akan diuji dikatakan baik apabila hasil dari uji chi square kecil. Semakin kecil nilai $\mathrm{X}^{2}$ semakin baik model tersebut, karena dalam uji bedachi square nilai $\mathrm{X}^{2}=0$ berarti tidak ada perbedaan. Tingkat signifikan penerimaan yang direkomendasikan adalah apabila $\mathrm{p} \geq 0.05$ atau $\mathrm{p} \geq 0.10$ (Hulland et al., 1996 dalam Ferdinad, 2006:59).

2. RMSEA (Root Mean Square Error of Approximation)

Nilai RMSEA menunjukkan goodness of fityang diharapkan bila model di estimasi dalam populasi. Nilai RMSEA yang lebih kecil atau sama dengan 0,08 merupakan indeks untuk dapat diterimanya model yang menunjukkan close of fitdari model itu didasarkan degrees of freedom. RMSEA merupakan indeks pengukuran yang tidak dipengaruhi oleh besarnya sampel, sehingga biasanya indeks ini digunakan untuk mengukur fit model pada

Page $\mid 20$ 
https://ejurnal.stimi-bjm.ac.id/index.php/JRIMK

jumlah sampel besar (Browne \& Cudeck, 1993 dalam Ferdinand, 2006:66).

3. GFI (Goodness of Fit Index)

GFI adalah ukuran relatif jumlah varians dan kovarians dalam S ( matriks kovarians data sampel) yang dijelaskan oleh $\sum$ (matriks kovarians populasi indeks kesesuaian (fit indeks) ini akan menghitung proporsi tertimbang dari varians dalam matriks kovarians sampel yang dijelaskan oleh matriks kovarians populasi yang terestimasikan. GFI adalah sebuah ukuran non-statistikal yang mempunyai rentang nilai antara 0 (poor fit) sampai dengan 1.0 (perfect fit). Nilai yang tinggi dalam indeks ini menunjukkan sebuah "Better Fit"(Bentler 1983 dalam Ferdinand, 2006:60).

4. AGFI(Adjusted Goodness of Fit Index)

Tingkat penerimaan yang direkomendasikan adalah bila AGFI mempunyai nilai sama dengan atau lebih besar dari 0.90 (Hair et al., 1995; Hulland et al., 1996 dalam Ferdinand, 2006:61). Nilai sebesar 0.95 dapat diinterprestasikan sebagai tingkatan yang baik-good overall model fit (baik) sedangkan besaran nilai antara 0.900.95 menunjukkan tingkatan cukup-adequate fit (Hulland et al., 1996 dalam Ferdinand, 2006:61).

5. CMIN/DF (Normed Chi Square)

Indeks ini diperoleh dengan cara CMIN dibagi dengan degree of freedom nya. Dalam hal ini CMIN/DF tidak lain adalah statistic chi-square, $X^{2}$ dibagi DF nya sehingga disebut $X^{2}$ relatif kurang dari 2.0 atau bahkan kadang kurang dari 3.0 adalah indikasi dari acceptable fit antara model dan data (Arbuckle, 1997 dalam Ferdinand, 2006:60).

6. TLI (Tucker-Lewis Index)

TLI adalah sebuah alternative incremental fit index yang membandingkan sebuah model yang diuji terhadap sebuah baseline model. Nilai yang direkomendasikan sebagai acuan untuk diterimanya sebuah model adalah penerimaan $\geq$ 0.95 (Hair et al., 1995 dalam Ferdinand, 2006;64), dan nilai yang sangat mendekati 1 menunjukkan a very good fit (Arbuckle, 1997 dalam Ferdinand, 2006:64).

7. CFI (Comparative Fit Index)

Besaran indeks ini adalah pada rentang nilai sebesar $0-1$, dimana semakin mendekati 1 , mengindikasikan tingkat fit yang paling tinggia very good fit (Arbuckle, 1997 dalam Ferdinand, 2006:64). Nilai yang direkomendasikan adalah $\mathrm{CFI} \geq 0.95$.

Secara ringkas, indeks-indeks yang dapat digunakan untuk menguji kelayakan sebuah model disajikan dalam tabel 1 berikut:
Tabel 1 : Pengujian Goodness Of Fit Index

\begin{tabular}{cc}
\hline Goodness Of Fit Indeks & Cut Of Value \\
\hline Chi Square & Diharapkan kecil \\
Significant Probability & $\geq 0.05$ \\
RMSEA & $\leq 0.08$ \\
GFI & $\geq 0.90$ \\
AGFI & $\geq 0.90$ \\
CMIN/DF & $\geq 2.00$ \\
TLI & $\geq 0.95$ \\
CFI & $\geq 0.95$ \\
\hline
\end{tabular}

Sumber : Ferdinand (2006:69)

\section{HASIL PENELITIAN DAN PEMBAHASAN}

Uji Asumsi Linieritas

Tabel 3: Hasil Pengujian Asumsi Linieritas

\begin{tabular}{|c|c|c|}
\hline $\begin{array}{l}\text { Hubunga } \\
\text { n Antar } \\
\text { Variabel }\end{array}$ & Hasil Pengujian & Keterangan \\
\hline $\mathrm{UIQ} \rightarrow \mathrm{Kp}$ & $\begin{array}{l}\text { Sig model linier } \\
0,001<0,05\end{array}$ & Linier \\
\hline $\mathrm{QI} \rightarrow \mathrm{Kp}$ & $\begin{array}{l}\text { Sig model linier } \\
0,001<0,05\end{array}$ & Linier \\
\hline $\mathrm{PP} \rightarrow \mathrm{Kp}$ & $\begin{array}{l}\text { Sig model linier } \\
0,000<0,05\end{array}$ & Linier \\
\hline $\mathrm{H} \rightarrow \mathrm{Kp}$ & $\begin{array}{l}\text { Sig model linier } \\
0,000<0,05\end{array}$ & Linier \\
\hline $\mathrm{UIQ} \rightarrow \mathrm{Ke}$ & $\begin{array}{l}\text { Sig model linier } \\
0,000<0,05\end{array}$ & Linier \\
\hline $\mathrm{QI} \rightarrow \mathrm{Ke}$ & $\begin{array}{l}\text { Sig model linier } 0,000< \\
0,05\end{array}$ & Linier \\
\hline $\mathrm{PP} \rightarrow \mathrm{Ke}$ & $\begin{array}{l}\text { Sig model linier } 0,000< \\
0,05\end{array}$ & Linier \\
\hline $\mathrm{Kp} \rightarrow \mathrm{Ke}$ & $\begin{array}{l}\text { Sig model linier } 0,000< \\
0,05\end{array}$ & Linier \\
\hline $\mathrm{Kp} \rightarrow \mathrm{LK}$ & $\begin{array}{c}\text { Sig model linier } 0,000< \\
0,05\end{array}$ & Linier \\
\hline $\mathrm{Ke} \rightarrow \mathrm{LK}$ & $\begin{array}{c}\text { Sig model linier } 0,000< \\
0,05\end{array}$ & Linier \\
\hline
\end{tabular}

Sumber: Data Diolah, 2020

Dari Tabel 3 terlihat bahwa semua pengaruh menghasilkan model linier yang signifikan (sig model linier $<0.05)$ sehingga asumsi linieritas terpenuhi.

\section{Hasil Uji Asumsi Outliers}

Evaluasi outliers dapat dilakukan secara univariate yaitu dengan menentukan nilai ambang batas yang akan dikategorikan sebagai outliers dengan cara mengkonversi nilai data penelitian ke dalam standard score dan evaluasi outliers secara multivariate yaitu dengan menggunakan jarak Mahalanobis untuk tiap-tiap observasi.

Kriteria yang digunakan adalah berdasarkan nilai Chi-Square pada tingkat derajat kebebasasn (degree of freedom) tertentu dan pada tingkat signifikansi (alpha) tertentu. Dalam studi ini, 
berdasarkan hasil analisis didapatkan nilai Jarak Mahalanobis terbesar yaitu pada observasi 11 sebesar 67,544, sedangkan nilai pembanding sebesar 178,485 yang didapatkan (Chi-Square Table df:149). Nilai Jarak Mahalanobis yang lebih kecil dari nilai pembanding menjelaskan bahwa tidak terdapat outliers pada seluruh pengamatan yang diobservasi, sehingga tidak ada pengamatan yang dikeluarkan dari model.

\section{Hasil Uji Ketepatan Model Goodness of Fit (GOF)}

Tahap pertama dari uji kecocokan ini ditujukan untuk mengevaluasi secara umum derajat kecocokan atau Goodness of Fit (GOF) antara data dengan model. SEM tidak mempunyai satu uji statistik terbaik yang dapat menjelaskan kekuatan prediksi model. Sebagai gantinya, beberapa ukuran GOF atau Goodness of Fit Indices (GOFI) dapat digunakan secara bersama-sama atau kombinasi. Tidak satupun dari ukuran-ukuran GOF atai GOFI secara eksklusif dapat digunakan sebagai dasar evaluasi kecocokan keseluruhan model. Petunjuk terbaik dalam menilai kecocokan model adalah teori substantive yang kuat. Jika model hanya menunjukkan atau mewakili teori substantive tang tidak kuat, dan meskipun model mempunyai kecocokan model yang sangat baik, agak sukar bagi kita untuk menilai model tersebut

Uji kecocokan keseluruhan model berkaitan dengan analisis terhadap GOF statistik yang dihasilkan oleh program, dalam hal ini AMOS. Dengan menggunakan pedoman ukuran-ukuran GOF dan hasil GOF statistic, maka dapat dilakukan analisis kecocokan keseluruhan model sebagai berikut:

Tabel 4. Evaluasi Kecocokan Model Struktural

\begin{tabular}{|c|c|c|c|}
\hline $\begin{array}{l}\text { Goodness of } \\
\text { fit Index }\end{array}$ & $\begin{array}{l}\text { Cut of } \\
\text { value }\end{array}$ & Hasil & Keterangan \\
\hline Chi-Square & $\begin{array}{c}\text { Diharapkan } \\
\text { kecil }\end{array}$ & 512,198 & $\begin{array}{l}\text { Model Poor } \\
\text { Fit }\end{array}$ \\
\hline Probability & $>0,050$ & 0,000 & $\begin{array}{l}\text { Model Poor } \\
\text { Fit }\end{array}$ \\
\hline CMIN/DF & $<2,000$ & 1,631 & $\begin{array}{l}\text { Model Good } \\
\text { Fit }\end{array}$ \\
\hline RMSEA & $<0,080$ & 0,065 & $\begin{array}{c}\text { Model Good } \\
\text { Fit }\end{array}$ \\
\hline GFI & $>0,900$ & 0,806 & $\begin{array}{c}\text { Model } \\
\text { Marginal Fit }\end{array}$ \\
\hline TLI & $>0,950$ & 0,915 & Model Fit \\
\hline CFI & $>0,950$ & 0,914 & Model Fit \\
\hline IFI & $>0,900$ & 0,904 & $\begin{array}{l}\text { Model Good } \\
\text { Fit }\end{array}$ \\
\hline AGFI & $>0,900$ & 0,767 & $\begin{array}{c}\text { Model } \\
\text { Marginal Fit }\end{array}$ \\
\hline
\end{tabular}

Sumber: Data Diolah, 2020

Berdasarkan hasil pada tabel 4 diperoleh nilai Chi-Square hitung $=512.198$ dan probability Chi Square $=0.000<0,05$ (Model Poor Fit), nilai CMIN/DF $=1.631<2.000($ Model Good Fit $) ;$ nilai
RMSEA $=0.065<0.080$ (Model Good Fit); Nilai GFI $=0.806<0.900$ (Model Marginal Fit) TLI = $0.915<0.850$ (Model Fit); Nilai CFI $=0.914>$ 0.950 (Model Fit); Nilai IFI $=0.915>0.900$ (Model Good Fit); dan Nilai AGFI $=0.767<0.900$ (Model Marginal Fit). Walau masih terdapat kriteria yang belum menyatakan Model Good Fit, namun secara keseluruhan semua kriteria sudah menyatakan Good Fit menunjukkan bahwa model SEM layak dan dapat diterima.

\section{Model Persamaan Struktural}

Model persamaan Struktural atau Struktural Equation Modeling (SEM), digunakan untuk menguji pengaruh di antara variabel penelitian yaitu Pengaruh UIQ, QI, PP, $H$ terhadap KL melalui Kp dan Ke. Pemodelan SEM terdiri dari measurement model dan structural model. Model pengukuran (measurement model) ditujukan untuk mengkonfirmasi masing-masing indikator yang dikembangkan pada sebuah faktor. Sedangan model structural (structural model) adalah model yang membahas mengenai struktur hubungan yang membentuk dan menjelaskan kausalitas antara variabel latent (Ferdinand, 2000).

\section{Model Pengukuran (Outer Model/Measurement Model)}

Tujuan dari model pengukuran (measurement model) untuk menunjukkan indikator yang memiliki pengaruh dominan sebagai pengukur langsung variabel latent. Evaluasi terhadap model pengukuran dapat dilakukan dengan melihat hasil estimasi loading factor atau weight faktornya yang paling dominan dengan melalui ranking pada tiap bobot faktor, rangking 1 merupakan indikator yang paling dominan. Hasil yang diperoleh sebagai berikut:

Tabel 5: Ringkasan Evaluasi Model Pengukuran

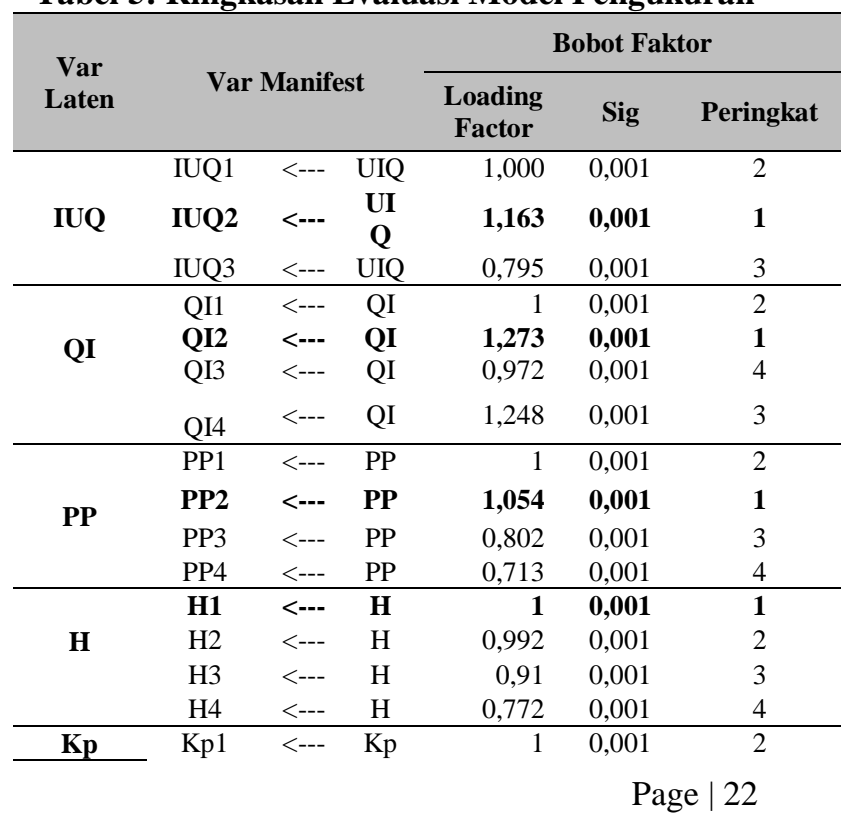




\begin{tabular}{|c|c|c|c|c|c|c|}
\hline \multirow{2}{*}{$\begin{array}{c}\text { Var } \\
\text { Laten }\end{array}$} & \multirow{2}{*}{\multicolumn{3}{|c|}{ Var Manifest }} & \multicolumn{3}{|c|}{ Bobot Faktor } \\
\hline & & & & \multirow{2}{*}{$\begin{array}{c}\begin{array}{c}\text { Loading } \\
\text { Factor }\end{array} \\
1,054\end{array}$} & \multirow{2}{*}{$\frac{\text { Sig }}{0,001}$} & \multirow{2}{*}{ Peringkat } \\
\hline & Kp2 & $<--$ & Kp & & & \\
\hline & Kp3 & $<---$ & Kp & 0,802 & 0,001 & 3 \\
\hline & Kp4 & $<---$ & $\mathrm{Kp}$ & 0,713 & 0,001 & 4 \\
\hline \multirow{4}{*}{$\mathbf{K e}$} & $\mathrm{Ke} 1$ & $<---$ & $\mathrm{Ke}$ & 1 & 0,001 & 3 \\
\hline & $\mathrm{Ke} 2$ & $<---$ & $\mathrm{Ke}$ & 0,857 & 0,001 & 4 \\
\hline & Ke3 & $<---$ & $\mathrm{Ke}$ & 1,262 & 0,001 & 2 \\
\hline & Ke4 & $<--$ & $\mathbf{K e}$ & 1,346 & 0,001 & 1 \\
\hline \multirow{4}{*}{ KL } & KL1 & $<--$ & KL & 1 & 0,001 & 4 \\
\hline & KL2 & $<---$ & KL & 1,047 & 0,001 & 3 \\
\hline & KL3 & $<---$ & KL & 1,095 & 0,001 & 1 \\
\hline & KL4 & $<--$ & $\mathrm{KL}$ & 1,059 & 0,001 & 2 \\
\hline
\end{tabular}

Sumber: Data Diolah, 2020

1. Indikator terbaik pembentuk variabel User Interface Quality (X1) adalah IUQ2 (Desain yang ditampilkan melalui foto merupakan design yang menarik) dengan loading faktor tertinggi $=1.163$, sehingga apabila pihak pengambil keputusan ingin meningkatkan nilai (X1) maka rekomendasi secara statistik adalah memprioritaskan perbaikan nilai pada indikator IUQ2. Pada variabel X1 didapatkan nilai loading faktor pada seluruh indikator variabel di atas 0,5 dan nilai signifikansi kurang dari 0,05 menjelaskan bahwa variabel User Interface Quality (X1) memiliki indikator yang valid dan dapat membentuk variabel tersebut dengan baik.

2. Indikator terbaik pembentuk variabel Kualitas Informasi (X2) adalah QI2 (Menyebutkan ukuran produk) dengan loading faktor tertinggi $=1,273$, sehingga apabila pihak pengambil keputusan ingin meningkatkan nilai (X2) maka rekomendasi secara statistik adalah memprioritaskan perbaikan nilai pada indikator QI2.

3. Indikator terbaik pembentuk variabel Persepsi Privasi (X3) adalah PP2 (Keyakinan informasi pribadi tidak tersebar) dengan loading faktor tertinggi $=1.054$, sehingga apabila pihak pengambil keputusan ingin meningkatkan nilai Persepsi Privasi (X3) maka rekomendasi secara statistik adalah memprioritaskan perbaikan nilai pada indikator PP2.

4. Indikator terbaik pembentuk variabel Harga (X4) adalah H1 (Harga produk yang jelas) dengan loading faktor tertinggi $=1$, sehingga apabila pihak pengambil keputusan ingin meningkatkan nilai (X4) maka rekomendasi secara statistik adalah memprioritaskan perbaikan nilai pada indikator $\mathrm{H} 1$.

5. Indikator terbaik pembentuk variabel Kepuasan (Y1) adalah KP2 (Keinginan yang terpenuhi) dengan loading faktor tertinggi $=1.054$, sehingga apabila pihak pengambil keputusan ingin meningkatkan nilai (Y1) maka rekomendasi secara statistik adalah memprioritaskan perbaikan nilai pada indikator KP2.

6. Indikator terbaik pembentuk variabel Kepercayaan (Y2) adalah Ke4 (Pelanggan akan membeli lebih banyak ketika UKM Sasirangan mengeluarkan produk baru) dengan loading faktor tertinggi $=1.346$, sehingga apabila pihak pengambil keputusan ingin meningkatkan nilai (Y2) maka rekomendasi secara statistik adalah memprioritaskan perbaikan nilai pada indikator Ke4.

7. Indikator terbaik pembentuk variabel Loyalitas (Y3) adalah KL3(Setia karena telah memberikan kepuasan) dengan loading faktor tertinggi $=1.095$, sehingga apabila pihak pengambil keputusan ingin meningkatkan nilai (Y3) maka rekomendasi secara statistik adalah memprioritaskan perbaikan nilai pada indikator KL3.

\section{Hasil Uji Hipotesis}

Secara keseluruhan, model pada penelitian ini terbagi atas pengaruh langsung dan pengaruh tidak langsung. Bagian ini berhubungan dengan evaluasi terhadap koefisien-kofisien atau parameterparameter yang menunjukkan hubungan kausal atau pengaruh satu variabel laten terhadap variabel laten lainnya. Sebuah hubungan kausal dinyatakan tidak signifikan jika nilai critical ratio (C.R.) berada diantara rentang -1.96 dan 1.96 dengan tingkat signifikansi 0,05 .

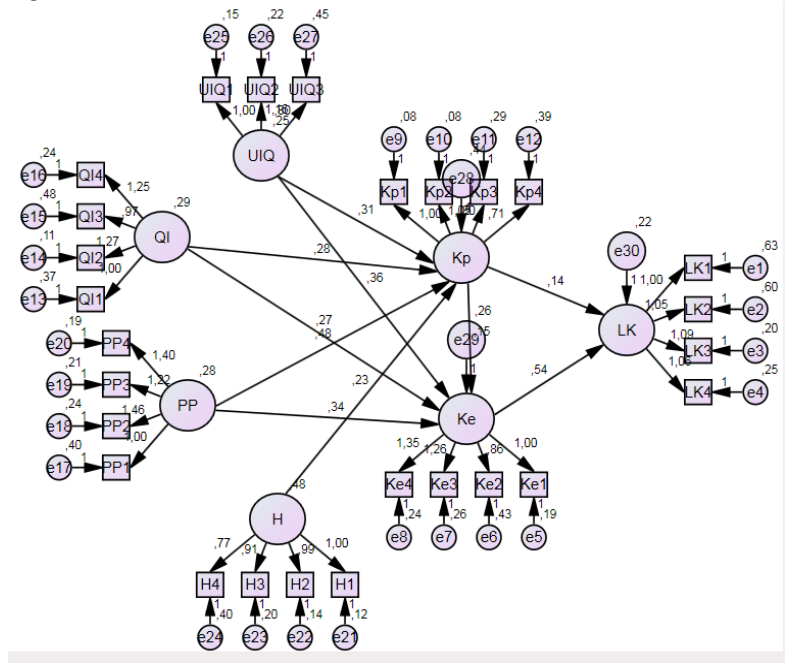

Path Diagram SEM (Outer dan Inner Model)

Tabel 6. Hasil Pengujian Hipotesis (Direct Effects)

\begin{tabular}{|c|c|c|c|c|c|}
\hline $\begin{array}{l}\text { Pengaruh } \\
\text { antar } \\
\text { variabel }\end{array}$ & H & $\begin{array}{c}\text { Koef } \\
\text { Jalur } \\
(\beta)\end{array}$ & $\begin{array}{l}t_{-} \\
\text {St } \\
\text { at }\end{array}$ & Sig & $\begin{array}{l}\text { Keputusan } \\
\text { Hipotesis }\end{array}$ \\
\hline $\begin{array}{l}\text { UIQ } \\
\quad(\mathrm{X} 1) \rightarrow \mathrm{Yp} 1)\end{array}$ & $\mathbf{H}_{1}$ & 0,314 & $\begin{array}{c}2,21 \\
7\end{array}$ & 0,027 & $\begin{array}{c}\mathbf{H}_{\mathbf{1}} \text { diterima } \\
: \boldsymbol{\beta}_{\mathbf{1}} \neq \mathbf{0} \\
\text { Berpengaruh } \\
\text { Positif }\end{array}$ \\
\hline
\end{tabular}




\begin{tabular}{|c|c|c|c|c|c|}
\hline $\begin{array}{c}\text { Pengaruh } \\
\text { antar } \\
\text { variabel }\end{array}$ & H & $\begin{array}{c}\text { Koef } \\
\text { Jalur } \\
(\beta)\end{array}$ & $\begin{array}{l}\mathrm{t}_{-} \\
\mathrm{St} \\
\text { at }\end{array}$ & Sig & $\begin{array}{c}\text { Keputusan } \\
\text { Hipotesis }\end{array}$ \\
\hline $\begin{array}{c}\text { UIQ } \\
(\mathrm{X} 1) \rightarrow \mathrm{Ke} \\
(\mathrm{Y} 2)\end{array}$ & $\mathbf{H}_{2}$ & 0,357 & $\begin{array}{c}2,90 \\
9\end{array}$ & 0,004 & $\begin{array}{c}\mathbf{H}_{2} \text { diterima : } \\
\boldsymbol{\beta}_{2} \neq \mathbf{0} \\
\text { Berpengaruh } \\
\text { Positif }\end{array}$ \\
\hline $\begin{array}{c}\mathrm{QI} \\
(\mathrm{X} 2) \rightarrow \mathrm{Kp} \\
(\mathrm{Y} 1)\end{array}$ & $\mathbf{H}_{3}$ & 0,276 & $\begin{array}{c}2,29 \\
6\end{array}$ & 0,022 & $\begin{array}{c}\text { H3diterima : } \\
\boldsymbol{\beta}_{\mathbf{3}} \neq \mathbf{0} \\
\text { Berpengaruh } \\
\text { Positif }\end{array}$ \\
\hline $\begin{array}{c}\mathrm{QI} \\
(\mathrm{X} 2) \rightarrow \mathrm{Ke} \\
(\mathrm{Y} 2)\end{array}$ & $\mathbf{H}_{4}$ & 0,274 & $\begin{array}{c}2,68 \\
1\end{array}$ & 0,007 & $\begin{array}{l}\text { H4diterima : } \\
\boldsymbol{\beta} \text { 4 } \neq \text { 0 } \\
\text { Berpengaruh } \\
\text { Positif }\end{array}$ \\
\hline $\begin{array}{c}\mathrm{PP} \\
(\mathrm{X} 3) \rightarrow \mathrm{Kp} \\
(\mathrm{Y} 1)\end{array}$ & H5 & 0,476 & $\begin{array}{c}3,35 \\
1\end{array}$ & 0,000 & $\begin{array}{c}\text { Hsditerima : } \\
\boldsymbol{\beta}_{\mathbf{5}} \neq \mathbf{0} \\
\text { Berpengaruh } \\
\text { Positif }\end{array}$ \\
\hline $\begin{array}{c}\mathrm{PP} \\
(\mathrm{X} 3) \rightarrow \mathrm{Ke} \\
(\mathrm{Y} 2)\end{array}$ & $\mathrm{H}_{6}$ & 0,343 & $\begin{array}{c}3,02 \\
6\end{array}$ & 0,002 & $\begin{array}{c}\text { Hoditerima : } \\
\boldsymbol{\beta}_{\mathbf{6}} \neq \mathbf{0} \\
\text { Berpengaruh } \\
\text { Positif }\end{array}$ \\
\hline $\begin{array}{c}\mathrm{H} \\
(\mathrm{X} 4) \rightarrow \mathrm{Kp} \\
(\mathrm{Y} 1)\end{array}$ & $\mathbf{H}_{7}$ & 0,226 & $\begin{array}{c}2,25 \\
2\end{array}$ & 0,024 & $\begin{array}{c}\text { H7diterima : }_{7} \\
\boldsymbol{\beta}_{7} \neq \mathbf{0} \\
\text { Berpengaruh } \\
\text { Positif }\end{array}$ \\
\hline $\begin{array}{l}\mathrm{Kp}(\mathrm{Y} 1) \\
\rightarrow \mathrm{Ke}(\mathrm{Y} 2)\end{array}$ & $\mathbf{H}_{8}$ & 0,148 & $\begin{array}{c}1,97 \\
8\end{array}$ & 0,048 & $\begin{array}{l}\text { H8 diterima } \\
\quad: \boldsymbol{\beta} \neq \neq 0 \\
\text { Berpengaruh } \\
\text { Positif }\end{array}$ \\
\hline $\begin{array}{c}\mathrm{Kp} \\
(\mathrm{Y} 1) \rightarrow \mathrm{LK} \\
(\mathrm{Y} 3)\end{array}$ & $\mathrm{H}_{9}$ & 0,145 & $\begin{array}{c}2,07 \\
5\end{array}$ & 0,038 & $\begin{array}{l}\text { H9 diterima } \\
\quad: \boldsymbol{\beta} \neq \mathbf{0} \\
\text { Berpengaruh } \\
\text { Positif }\end{array}$ \\
\hline $\begin{array}{c}\mathrm{Ke} \\
(\mathrm{Y} 2) \rightarrow \mathrm{LK} \\
(\mathrm{Y} 3)\end{array}$ & $\mathbf{H}_{10}$ & 0,542 & $\begin{array}{c}5,03 \\
3\end{array}$ & 0,001 & $\begin{array}{c}\mathbf{H}_{\mathbf{1 0}} \text { diterima } \\
: \boldsymbol{\beta}_{\mathbf{1 0}} \neq \mathbf{0} \\
\text { Berpengaruh } \\
\text { Positif }\end{array}$ \\
\hline
\end{tabular}

Sumber: Data Diolah, 2020

1. Variabel User Interface Quality (X1) dengan nilai t statistik (2.217) lebih besar dari nilai $t$ tabel $(1,960)$ dan nilai sig (0.027) kurang dari 0.05 maka Ho ditolak dan Ha diterima, artinya User Interface Quality berpengaruh terhadap Kepuasan. Maka hipotesis I terbukti bahwa User Interface Quality mempunyai pengaruh terhadap Kepuasan. Nilai koefisien jalur (0.314) menunjukkan jika variabel User Interface Quality memiliki pengaruh positif terhadap Kepuasan . Hasil analisis ini menunjukkan bahwa semakin baik User Interface Quality(X1) maka akan meningkatkan Kepuasan (Y1).

2. Variabel User interface quality (X1) memiliki nilai $\mathrm{t}$ statistik (2.909) lebih besar dari nilai $\mathrm{t}$ tabel $(1,960)$ dan nilai sig sebesar 0.004 yang kurang dari 0.05 maka Ho ditolak dan $\mathrm{Ha}$ diterima, artinya User Interface Quality (X1)

berpengaruh terhadap Kepercayaan (Y2). Maka hipotesis 2 terbukti bahwa User Interface Quality mempunyai pengaruh terhadap Kepercayaan. Nilai koefisien jalur sebesar 0.357 menunjukkan jika variabel User Interface Quality (X1) memiliki pengaruh positif terhadap Kepercayaan (Y2).

3. Variabel Kualitas Informasi (X2) nilai t statistik (2.296) lebih besar dari nilai t tabel $(1,960)$ dan nilai sig sebesar 0.022 yang kurang dari 0.05 maka Ho ditolak dan $\mathrm{Ha}$ diterima, artinya Kualitas Informasi(X2) berpengaruh terhadap Kepuasan (Y1). Dengan demikian hipotesis 3 terbukti bahwa Kualitas Informasi mempunyai pengaruh terhadap Kepuasan. Nilai koefisien jalur sebesar 0.276 menunjukkan jika variabel Kualitas Informasi (X2) memiliki pengaruh positif terhadap Kepuasan (Y1).

4. Variabel Kualitas Informasi (X2) memiliki nilai t statistik (2.681) lebih besar dari nilai t tabel $(1,960)$ dan nilai sig sebesar 0.007 yang kurang dari 0.05 maka Ho ditolak dan $\mathrm{Ha}$ diterima, artinya Kualitas Informasi (X2) berpengaruh terhadap Kepercayaan (Y2). Nilai koefisien jalur (0.274) menunjukkan jika variabel Kualitas Informasi (X2) memiliki pengaruh positif Kepercayaan (Y2) berarti semakin baik Kualitas Informasi akan meningkatkan kepercayaan.

5. Variabel Persepsi Privasi (X3) nilai t statistik (3.351) lebih besar dari nilai t tabel $(1,960)$ dan nilai sig sebesar 0.001 yang kurang dari 0.05 maka Ho ditolak dan Ha diterima, artinya Persepsi Privasi (X3) berpengaruh terhadap Kepuasan (Y1). Nilai koefisien jalur (0.476) menunjukkan jika Persepsi Privasi (X3) memiliki pengaruh positif terhadap Kepuasan (Y1). Hasil analisis ini menunjukkan bahwa semakin baik Persepsi Privasi (X3) maka akan meningkatkan Kepuasan (Y1)

6. Variabel Persepsi Privasi (X3) nilai t statistik (3.026) lebih besar dari nilai t tabel $(1,960)$ dan nilai sig sebesar 0.002 yang kurang dari 0.05 maka Ho ditolak dan Ha diterima, artinya Persepsi Privasi(X3) berpengaruh terhadap Kepercayaan (Y2). Nilai koefisien jalur (0.343) menunjukkan jika Persepsi Privasi (X3) memiliki pengaruh positif terhadap Kepercayaan (Y2). Hasil analisis ini menunjukkan bahwa semakin baik Persepsi Privasi (X3) maka akan meningkatkan Kepercayaan (Y2).

7. Variabel Harga (X4) memiliki nilai t statistik (2.252) lebih besar dari nilai t tabel $(1,960)$ dan nilai sig sebesar 0.024 yang kurang dari 0.05 maka Ho ditolak dan Ha diterima, artinya Harga (X4) berpengaruh terhadap Kepuasan (Y1). Nilai koefisien jalur (0.226) menunjukkan jika 
variabel variabel Harga (X4) memiliki pengaruh positif terhadap Kepuasan (Y1). Hasil analisis ini menunjukkan bahwa semakin baik kebijakan Harga (X4) maka akan meningkatkanKepuasan (Y1).

8. Variabel Kepuasan (Y1) memiliki nilai t statistik (1.978) lebih besar dari nilai t tabel $(1,960)$ dan nilai sig sebesar 0.048 yang kurang dari 0.05 maka Ho ditolak dan Ha diterima, artinya Kepuasan(Y1) berpengaruh terhadap Kepercayaan (Y2). Nilai koefisien jalur (0.158) menunjukkan jika variabel Kepuasan (Y1) memiliki pengaruh positif terhadap Kepercayaan (Y2). Hasil analisis ini menunjukkan bahwa semakin baik Kepuasan (Y1) maka akan meningkatkan Kepercayaan (Y2).

9. Variabel Kepuasan (Y1) memiliki nilai t statistik (2.075) lebih besar dari nilai t tabel $(1,960)$ dan nilai sig sebesar 0.038 yang kurang dari 0.05 maka Ho ditolak dan Ha diterima, artinya Kepuasan(Y1) berpengaruh terhadap Loyalitas (Y3). Nilai koefisien jalur (0.145) menunjukkan jika variabel $\operatorname{Kepuasan}(\mathrm{Y} 1)$ memiliki pengaruh positif terhadap Loyalitas (Y3).

10. Variabel Kepercayaan(Y2) memiliki nilai $t$ statistik (5.033) lebih besar dari nilai t tabel $(1,960)$ dan nilai sig sebesar 0.001 yang kurang dari 0.05 maka Ho ditolak dan $\mathrm{Ha}$ diterima, artinya Kepercayaan (Y2) berpengaruh terhadap Loyalitas (Y3). Nilai koefisien jalur (0.542) menunjukkan jika variabel Kepercayaan (Y2) memiliki pengaruh positif terhadap Loyalitas (Y3). Hasil analisis ini menunjukkan bahwa semakin baik Kepercayaan (Y2) maka akan meningkatkan Loyalitas (Y3).

\section{A. Implikasi Teoritis}

Pengaruh User Interface Quality terhadap Kepuasan

Hasil pengujian hipotesis I diketahui bahwa User Interface Quality mempunyai pengaruh signifikan terhadap kepuasan pelanggan. Hal ini seperti yang dikemukakan Park, $\mathrm{CH} \& \mathrm{Kim}, \mathrm{YG}$ (2003) bahwa User Interface quality mempengaruhi kepuasan pelanggan secara langsung, karena memberikan bukti fisik dari kompetensi penyedia layanan serta memfasilitasi penggunaan layanan yang mudah. User Interface Quality atau yang lebih dikenal dengan tampilan instagram menunjukkan semua informasi yang ingin diketahui oleh konsumen dalam hal ini pengguna instagram. Hal ini menunjukkan bahwa perusahaan harus mampu mendesain instagram dengan lebih menarik. dan untuk foto yang ditampilkan merupakan foto yang yang menggambarkan bagaimana desain sasirangan sehingga dapat membuat pelanggan tertarik dan akhirnya akan melakukan pembelianHasil penelitian ini mendukung penelitian yang dilakukan oleh Eid, MI (2011) dan Dhiranty et al. (2017) yang menemukan bahwauser interface quality memiliki pengaruh positif pada kepuasan konsumen.

\section{Pengaruh User Interface Quality terhadap Kepercayaan}

Hasil pengujian hipotesis II menunjukkan jika User Interface Quality berpengaruh signifikan terhadap kepercayaan pelanggan. Hal ini seperti yang dikemukakan oleh Gummerus, Johanna et al. (2004) bahwa User Interface qualitydapat mempengaruhi kepercayaan secara langsung serta kemudahan navigasi, desain antarmuka, dan panduan pengguna mempengaruhi pembentukan kepercayaan konsumen. Dalam jual beli online maka konsumen tidak melihat secara langsung produk yang akan dijual, melalui media instagram maka penjual dapat memberikan semua informasi mengenai produk dan semua hal yang berhubungan dengan produk yang akan ditawarkan pada konsumen. Maka dari itu untuk dapat membangun dan meningkatkan kepercayaan konsumen maka pihak penjual harus dapat membuat dan mendesain tampilan instagram dengan menarik. Hasil penelitian ini mendukung penelitian yang dilakukan oleh Eid, MI (2011) dan Dhiranty et al. (2017) yang menemukan bahwa user interface quality memiliki pengaruh positif pada kepercayaan konsumen.

\section{Pengaruh Kualitas Informasi terhadap Kepuasan}

Hasil pengujian hipotesis III diketahui bahwa Kualitas Informasi mempunyai pengaruh signifikan terhadap kepuasan pelanggan. Hal ini seperti yang dikemukakan Park, CH \& Kim, YG (2003) bahwa kualitas informasi produk didefinisikan sebagai persepsi pelanggan terhadap kualitas informasi tentang produk yang disediakan oleh situs online sehingga sangat memberikan pengaruh langsung terhadap kepuasan pelanggan. Kualitas informasi adalah persepsi konsumen dari kualitas informasi produk yang pro-vided oleh situs web e-commerce. Hal ini penting, relevansi, kegunaan, dan lain-lain dengan informasi produk yang diberikan oleh situs e-commerce (Brilliant \&Achyar2013). Hasil penelitian ini mendukung hasil penelitian Eid, MI (2011) dan Dhiranty et al. (2017) yang menemukan bahwa kualitas informasi memiliki pengaruh positif pada kepuasan konsumen.

\section{Pengaruh Kualitas Informasi terhadap Kepercayaan}

Hasil pengujian hipotesis IV menunjukkan jika Kualitas informasi mempunyai pengaruh signifikan terhadap kepercayaan. Hal ini seperti yang dikemukakan oleh Park dan Kim (2003) bahwa kualitas informasi produk didefinisikan sebagai persepsi pelanggan terhadap kualitas informasi tentang produk yang disediakan oleh situs 
online sehingga sangat memberikan pengaruh langsung terhadap kepercayaan pelanggan Kualitas informasi adalah persepsi konsumen dari kualitas informasi produk yang pro-vided oleh situs web ecommerce. Hal ini penting, relevansi, kegunaan, dan lain-lain dengan informasi produk yang diberikan oleh situs e-commerce (Brilliant \&Achyar2013). Hasil penelitian ini mendukung hasil penelitian Dhiranty et al. (2017) dan Brilliant \& Achyar (2013) yang menyatakan bahwa kualitas informasi memiliki pengaruh positif pada kepercayaan konsumen.

\section{Pengaruh Persepsi Privasi terhadap Kepuasan}

Hasil pengujian hipotesis $\mathrm{V}$ menunjukkan bahwa persepsi privasi mempunyai pengaruh yang signifikan terhadap kepuasan. Menurut Flavianus dan Guinalíu (2006) bahwa persepsi privasi mengacu pada jaminan teknis yang memastikan bahwa persyaratan hukum dan praktik yang baik terkait privasi akan dipenuhi secara efektif. Misalnya, perusahaan dapat berjanji bahwa data tidak akan diberikan kepada pihak ketiga tanpa persetujuan pelanggan, hal ini dapat menimbulkan kepuasan pelanggan terhadap perusahaan tersebut. Hasil penelitian ini mendukung penelitian dilakukan oleh Dhirantyet al. (2017) yang menemukan bahwa persepsi privasi memiliki pengaruh positif pada kepuasan.

\section{Pengaruh Persepsi Privasi terhadap Kepercayaan}

Hasil pengujian hipotesis VI menunjukkan bahwa persepsi privasi mempunyai pengaruh yang signifikan terhadap kepercayaan. Persepsi privasi menunjukkan persepsi konsumen terhadap keamanan berbagi informasi pribadi dalam transaksi online. Ini adalah keyakinan konsumen bahwa informasi pribadi mereka tidak akan digunakan, dilihat, atau disimpan oleh pihak yang tidak berkepentingan (Brilliant \& Achyar 2013). Adanya jaminan keamanan tersebut akan membentuk kepercayaan pelanggan pada perusahaan online. Hal ini menunjukkan jika perusahaan harus dapat menjaga privasi pelanggan dalam bertransaksi karena banyak informasi pribadi konsumen yang dapat diakses melalui media online termasuk instagram. Sehingga jika ingin mendapatkan dan meningkatkan kepercayaan pelanggan maka perusahaan harus dapat menjaga privasi konsumen. Hasil penelitian ini mendukung penelitian yang dilakukan oleh Eid, MI (2011) dan Dhirantyet al. (2017) yang menemukan bahwa persepsi privasi memiliki pengaruh positif pada kepercayaan konsumen.

\section{Pengaruh Harga terhadap Kepuasan}

Hasil pengujian hipotesis VII menunjukkan bahwa harga mempunyai pengaruh yang signifikan terhadap kepuasan pelanggan. Menurut Hermann et al., (2007) harga didefinisikan sebagai value suatu produk atau jasa untuk individu ketika produk atau jasa tersebut memberikan manfaat yang berbeda jasa. Konsumen memandang harga sebagai nilai barang yang mampu memberikan manfaat atas pemenuhan kebutuhan dan keinginannya (misalkan hemat, prestise, syarat pembayaran, dan sebagainya).Hasil penelitian ini mendukung hasil penelitian Hasniaty (2015) dan Shartykarini, S (2016) yang dalam penelitiannya menemukan bahwa harga yang terjangkau dapat memberikan kepuasan konsumen.

\section{Pengaruh Kepuasan terhadap Kepercayaan}

Hasil pengujian hipotesis VIII menunjukkan bahwa kepuasan mempunyai pengaruh yang signifikan terhadap kepercayaan. Kepuasan menurut Kotler dan Keller (2009:177) adalah perasaan senang atau kecewa seseorang yang muncul setelah membandingkan kinerja (hasil) produk yang dipikirkan terhadap kinerja (atau hasil) yang diharapkan. Kepuasan pelanggan terletak pada ekspektasi pelanggan terhadap suatu produk. Pelanggan akan merasa puas jika produk yang mereka peroleh sesuai dengan yang pelanggan inginkan akan produktersebut. Ketika pelanggan puas terhadap suatu produk maka kepercayaan pelanggan akan meningkat dan akan terus menggunakan produk tersebut. Hasil penelitian ini mendukung hasil penelitian Dhiranty et al (2017) yang menemukan bahwa kepuasaan mempunyai pengaruh terhadap kepercayaan.

\section{Pengaruh Kepuasan terhadap Loyalitas}

Hasil pengujian hipotesis IX menunjukkan bahwa kepuasan mempunyai pengaruh yang signifikan terhadap loyalitas pelanggan. Kepuasan pelanggan pada dasarnya merupakan tujuan dari suatu bisnis, karena dengan terciptanya kepuasan pelanggan akan memberikan beberapa manfaat positif bagi perusahaan, diantaranya terciptanya hubungan yang harmonis antara perusahaan dan pelanggannya, serta memberikan dasar yang baik bagi pembelian ulang dan terciptanya loyalitas pelanggan. Hal ini seperti yang dikemukakan Tjiptono (2000:105) bahwa terciptanya kepuasan dapat memberikan beberapa manfaat, diantaranya hubungan antara perusahaan dengan pelanggannya menjadi harmonis sehingga memberikan dasar yang baik bagi pembelian ulang dan terciptanya kesetiaan terhadap merek serta membuat suatu rekomendasi dari mulut ke mulut (word of mouth) yang menguntungkan bagi perusahaan.Hasil penelitian ini mendukung hasil penelitian Eid, MI (2011), Wulandari dkk (2016) dan Hidayat, DR (2014) yang menemukan bahwa kepuasan positif mempengaruhi loyalitas pelanggan.

\section{Pengaruh Kepercayaan terhadap Loyalitas}

Hasil pengujian hipotesis $\mathrm{X}$ menunjukkan bahwa kepercayaan mempunyai pengaruh yang signifikan terhadap loyalitas. Kolsaker dan Payne 
(2002) mendefinisikan kepercayaan sebagai dimensi hubungan bisnis yang menentukan tingkat di mana masing-masing pihak merasa dapat mengandalkan integritas janji yang ditawarkan oleh pihak lain.Mengembangkan kepercayaan meskipun ada perdebatan tentang sifat dari kepercayaan, secara kontekstual kepercayaan berkaitan dengan keyakinan bahwa seseorang memiliki tentang niat pihak lain dalam suatu hubungan.Kepercayaan merupakan hal penting yang akan menentukan hubungan jangka panjang antara penjual dengan pelanggannya.Hal ini seperti yang dikemukakan oleh Wulandari (2016) bahwa kepercayaan merupakan karakter terpenting dalam mewujudkan hubungan jangka panjang di masa depan.Ketika pelanggan percaya terhadap suatu produk, maka pelanggan akan terus menerus menggunakan produk tersebut bahkan akan merekomendasikan kepada orang lain. Hasil penelitian ini mendukung hasil penelitian Dhiranty et al (2017), Brilliant \& Achyar (2013) dan Hasniaty (2015) yang menemukan bahwa kepercayaan positif mempengaruhi loyalitas pelanggan.

\section{Implikasi Manajerial}

Kasasiur Banjar Sasirangan merupakan salah satu pelaku usaha UKM yang memanfaatkan media sosial instagram sebagai sarana untuk memasarkan produknya. Kasasiur Banjar Sasirangan menyadari pentingnya media social guna mendukung perusahaan dalam mencapai tujuan dalam aktivitas pemasaran. Guna keberhasilan pemasaran maka setiap perusahaan tentu menginginkan agar pelanggannya tetap setia, tidak berpindah dan melakukan pembelian ulang atau dengan kata lain membuat pelanggan menjadi loyal. Dengan loyalitas pelanggan maka perusahaan akan dapat bertahan hingga jangka waktu yang panjang..

Guna mempertahankan dan bahkan meningkatkan loyalitas pelanggan maka perusahaan berupaya mewujudkan kepuasan pelanggan dan meningkatkan kepercayaan pelanggannya. Sebagai online shop makapemilik toko onlineharus mengetahui dan memenuhi keinginanpelanggan agar percaya dan menjadi pelangganyang loyal. Pemilik toko online harus memberikan pelayanan terbaik mereka dengan cara memperhatikan userinterface quality, kualitas informasi, persepsi privasi dan harga untuk mewujudkan kepuasan pelanggan dan mendapatkan kepercayaan (trust) dan selanjutnya menimbulkan loyalitas (loyality) pelanggan.

User interface qualityadalah aspek nyata dari internet melalui media sosial, hal ini merupakan saluran interaksi antara konsumen dan penyedia layanan elektronik dalam hal ini UKM yang meliputi desain situs dan searchability. Desain website bisnis online harus dibuat menarik secara visual. Salah satu bentuk kepercayaan konsumen pada bisnis online jika bisnis online tersebut memiliki penampilan yang profesional karena akan memberikan image positif bagi konsumen. Selain itu searchbility yang merupakan kemudahan konsumen dalam mencari akun penjual pada media sosial instagram juga merupakan hal penting yang harus diperhatikan. Kemudahan untuk mencari atau mengakses suatu situs memberikan suatu kenyamanan bagi pelanggan khususnya untuk mencari produk yang dibutuhkan.

Kualitas informasi menjadi factor lain dalam situs online yang menjadi perhatian pelanggan dalam mengunjungi akun penjual online. Informasi yang disajikan dalam instagramharus mampu memberikan informasi secara detail tentang produk yang dijual, cara pemakaian, dan lain sebagainya. Dari informasi yang disajikan tersebut akan menimbulkan kepercayaan pelanggan terhadap akun penjual dan kepuasan pelanggan sehingga akhirnya akan mempengaruhi loyalitas pelanggan.

Berkaitan dengan keamanan privasi pelanggan maka pada saat melakukan pembelian melalui media online, terdapat beberapa data pelanggan yang diketahui oleh penjual. Banyak informasi pribadi pelanggan yang dapat diakses melalui media online. Suatu bisnis harus dapat menjaga privasi pelanggan. Oleh sebab itu, penjual diharuskan dapat menjaga kerahasiaan identitas pembeli. Selain itu, pihak penjual juga harus memberikan jaminan bahwa transaksi pembelian berlangsung secara aman.Pelanggan akan lebih mengutamakan berbisnis dengan bisnis online yang mampu menjamin kemanan transaksi. Adanya jaminan kerahasiaan peribadi konsumen akan membuat konsumen puas dan percaya dengan akun penjual online sehingga akan mewujudkan loyalitas pelanggan.

Dalam melakukan pembelian, maka pelanggan akan mempertimbangkan harga produk yang dijual. Harga merupakan hal penting,karena setiap harga yang ditetapkan oleh perusahaan akan mengakibatkan tingkat permintaan terhadap produk berbeda. Harga dapat menunjukkan kualitas merek dari suatu produk,dimana konsumen mempunyai anggapan bahwa harga yang mahal biasanya mempunyai kualitas yang baik. Pentingnya harga maka dalam media instagram harus mencantumkan harga produk dengan jelas, dapat dimengerti, sesuai dengan kualitas produk yang ditampilkan serta dapat bersaing dengan produk pesaing lainnya.

Menjalankan bisnis online mutlak memerlukan kepercayaan satu sama lain, baik penjual maupun pembelinya. Jika tidak ada rasa saling percaya, mustahil transaksi bisa dilakukan. Untuk itu, setiap perusahaan atau siapa pun yang akan melakukan bisnis online, mereka perlu menjaga kepercayaan dari pelanggannya. 
Kepercayaan pelanggan akan membuat pelanggan membeli lebih banyak ketika perusahaan dalam hal ini UKM Sasirangan mengeluarkan produk baru. Maka dari itu, perusahaan harus terus berinovasi menghasilkan produk baru yang sesuai dengan keinginan dan kebutuhan pelanggannya.

Kepuasan pelanggan merupakan kunci dalam menciptakan loyalitas pelanggan. Terciptanya kepuasan konsumen akan memberikan manfaat positif bagi perusahaan diantaranya terciptanya hubungan yang harmonis antara perusahaan dan pelanggannya, serta memberikan dasar yang baik bagi pembelian ulang dan terciptanya loyalitas pelanggan. Guna mewujudkan kepuasan pelanggan maka perusahaan harus dapat memenuhi kebutuhan, keinginan dan harapan pelanggan diantaranya dengan memberikan produk yang sesuai dengan yang ditawarkan dalam instagram. Salah satu hambatan yang dialami perusahaan adalah dari segi warna, tidak sesuai dengan foto yang ditampilkan pada instagram. Kasasiur Banjar menjelaskan bahwa untuk pewarnaan agak sulit untuk menjelaskannya, tetapi pada foto yang ditampilkan pada instagram selalu diberikan informasi bahwa warna dapat berbeda dengan aslinya karena pengaruh kamera foto, proses editing dan layar masing-masing Smartphone.

\section{PENUTUP \\ Simpulan}

Berdasarkan pengujian secara statistik menghasilkan beberapa temuan yang dapat disimpulkan sebagai berikut:

1. User Interface quality memiliki pengaruh positif signifikan terhadap kepuasan pelanggan. Hasil analisis menunjukkan bahwa semakin baik User Interface quality maka akan meningkatkan kepuasan pelanggan.

2. User Interface quality memiliki pengaruh positif signifikan terhadap kepercayaan pelanggan. Hasil analisis menunjukkan bahwa semakin baik User Interface quality maka akan meningkatkan kepercayaan pelanggan.

3. Kualitas informasi memiliki pengaruh positif signifikan terhadap kepuasan pelanggan. Hasil analisis menunjukkan bahwa semakin baik kualitas informasi maka akan meningkatkan kepuasan pelanggan.

4. Kualitas informasi $t$ memiliki pengaruh positif signifikan terhadap kepercayaan pelanggan. Hasil analisis menunjukkan bahwa semakin baik Kualitas informasi maka akan meningkatkan kepercayaan pelanggan.

5. Persepsi privasi memiliki pengaruh positif signifikan terhadap kepuasan pelanggan. Hasil analisis menunjukkan bahwa semakin baik persepsi privasi maka akan meningkatkan kepuasan pelanggan.

6. Persepsi privasi memiliki pengaruh positif signifikan terhadap kepercayaan pelanggan. Hasil analisis menunjukkan bahwa semakin baik persepsi privasi maka akan meningkatkan kepercayaan pelanggan.

7. Harga memiliki pengaruh positif signifikan terhadap kepuasan pelanggan. Hasil analisis menunjukkan bahwa semakin baik kebijakan harga maka akan meningkatkan kepuasan pelanggan.

8. Kepuasan pelanggan memiliki pengaruh positif signifikan terhadap kepercayaan. Hasil analisis menunjukkan bahwa semakin baik kepuasan pelanggan maka akan meningkatkan kepercayaan pelanggan.

9. Kepuasan pelanggan memiliki pengaruh positif signifikan terhadap loyalitas pelanggan. Hasil analisis menunjukkan bahwa semakin baik kepuasan pelanggan maka akan meningkatkan loyalitas pelanggan.

10. Kepercayaan pelanggan memiliki pengaruh positif signifikan terhadap loyalitas pelanggan. Hasil analisis menunjukkan bahwa semakin baik kepercayaan pelanggan maka akan meningkatkan loyalitas pelanggan.

\section{Saran}

1. Hendaknya UKM dalam meningkatkan user interface quality lebih memperhatikan desain yang ditampilkan melalui foto dengan membuat desain yang menarik karena foto yang ditampilkan akan dilihat pelanggan dan mempengaruhi penilaian pelanggan terhadap produk yang ditampilkan.

2. Guna meningkatkan kualitas informasi melalui media instagram maka hendaknya UKM lebih menyebutkan jenis bahan produk secara detail agar pelanggan memperoleh informasi yang jelas dan lengkap mengenai produk yang ditawarkan melalui media instagram sesuai dengan yang diinginkan.

3. UKM hendaknya lebih memperhatikan jaminan bahwa infomasi pribadi pelanggan tidak tersebar, mengingat melalui media instagram banyak data pribadi pelanggan yang bisa diketahui UKM. Dengan adanya jaminan ini akan membuat pelanggan merasa aman dan meningkatkan kepercayaan pelanggan pada UKM.

4. Sebaiknya UKM juga memperhatikan harga produk yang jelas dalam gambar setiap produk yang ditawarkan. Hal ini selain memberikan infomasi yang lebih jelas juga dapat menjadi salah satu media untuk mempengaruhi penilaian pelanggan agar mau membeli produk yang ditawarkan. 
5. Guna meningkatkan kepuasan pelanggan maka hendaknya UKM memperhatikan keinginan pelanggan diantaranya dengan melakukan survey secara online berhadiah guna mengenai keinginan pelanggan dan berupaya untuk memenuhi keinginan pelanggan.

6. Guna membentuk kepercayaan pelanggan maka hendaknya UKM terus berinovasi membuat produk baru sesuai selera dan keinginan pelanggan. Menginat persaingan yang makin tajam dan permintaan pelanggan yang selalu berubah maka inovasi produk menjadi salah satu hal penting guna menjaga kepercayaan pelanggan.

7. Guna meningkatkan loyalitas pelanggan maka henaknya UKM harus dapat mewujudkan dan menjaga kepuasan pelanggan, diantaranya dengan memberikan respon cepat (fast respons) terhadap pertanyaan pelanggan dan serta komplain dari pelanggan. Dengan respon yang cepat dari UKM akan membuat pelanggan puas dan loyal terhadap UKM.

8. Bagi penelitian yang akan datang diharapkan dapat memperluas objek/responden penelitian untuk memperoleh hasil yang lebih akurat serta perlu menambahkan variabel lain dari faktorfaktor yang dapat mempengaruhi kepuasan pelanggan, kepercayaan dan loyalitas pelanggan sehingga diperoleh hasil yang lebih luas dan akurat.

\section{DAFTAR PUSTAKA}

Ariwibowo, DPJ \&Nugroho, MA 2013, Pengaruh Trust Dan Perrcieved Of Risk Terhadap Niat Untuk Bertransaksi Menggunakan ECommerce, Jurnal Nominal, Vol. II, No.1.

Armstrong, G \& Kotler, P 2003, Marketing An Introduction, Edisi 6, USA: Prentice Hall.

Brendon, CF 2002, InEcommece, customers trust is no longer an option: it is the requirement for success, Annual Quality Congress Proceedings.

Brilliant, MA\&Achyar, A 2013, The Impact of Satisfaction And Trust On Loyalty of ECommerce Consumers, ASEAN Marketing Journal, Vol.V, No.1.

Dhiranty, A, Suharjo, B, \&Suprayitno, G 2017, An Analysis On Customer Satisfaction, Trust And Loyalty Toward Online Shop (A Case Study Of Tokopedia.Com), Journal Of Business And Entrepreneurship, Vol.3, No.2.

Eid, MI 2011, Determinants Of E-Commerce Customer Satisfaction, Trust, And Loyalty In Saudi Arabia, Journal of Electronic Commerce Research, Vol. 12, No.1.

Ferdinand, Augusty 2006, Structural Equation Modeling Dalam Penelitian Manajemen, Edisi
4, Semarang: Badan Penerbit Universitas Diponegoro.

Flavian, C \& Guinaliu, M 2006, Consumer trust, perceived security and privacy policy Three basic elements of loyalty to a web site, Industrial Management \& Data Systems, Vol.106, No.5.

Ghozali, Imam 2016, Model Persamaan Struktural Konsep Dan Aplikasi Dengan Program AMOS 24 Edisi 7 Update Bayesian SEM, Semarang: Badan Penerbit Universitas Diponegoro

Gummerus, Johanna dkk2004, Customer loyalty to content-basedWebsites: the case of an online health-care service, Journal of Services Marketing, Vol. 18, No.3

Gunawan, Alif 2013, Komunikasi Interpersonal dan Fasilitas Kesehatan; Pengaruhnya terhadap Kepercayaan, Loyalitas danWom RumahSakit (Online), Vol.1, No.3

Hasniaty 2015, Customer Perception On Products, Pricing, Service Quality, Towards Customer's Quality Relationships And Loyalty Of Domestic Airlines, Indonesia, International Journal Of Scientific \& Technology Research, Vol.4, No.12.

Hermann, A., Xia, L., Monroe, K. B., \& Huber, F 2007. The influence of price fairness on customer satisfaction: an empirical test in the context of automobile purchases. Journal of Product \& Brand Management , 49 - 58.

Hidayat, DR 2014, Analisis Pengaruh Kualitas Layanan, harga, Kepercayaan, Citra Perusahaan, Dan Kepuasaan Pelanggan Terhadap Loyalitas Pelanggan, Jurnal Wawasan Manajemen, Vol.2, No.3.

https://jelajahdigital.com/data-dan-fakta-instagramdalam-statistik/. DiaksespadaTanggal 10 Mei 2019.

Kolsaker, A \& Payne, C 2002, Engendering Trust in E-Commerce: a study of Gender-Based Concerns, Marketing intelligence \& Planning, Vol.13, No.4.

Kotler, P \& Keller, KL 2009, ManajemenPemasaran, Edisi 12, Jilid 1, Jakarta: PT. Indeks.

Malhotra, NK, 2004, Riset Pemasaran: Pendekatan Terapan, Edisi Keempat, Jilid 1, Jakarta:PT. Indeks Kelompok Gramedia.

Norhermaya, YA \&Soesanto, S 2016, Analisis Pengaruh Kepuasan Pelanggan terhadap Kepercayaan dan Loyalitas Pelanggan untuk Meningkatkan Minat Beli Ulang (Studi pada Online Store Lazada,Co.Id), Vol.5, No.3

Park, CH \& Kim, YG 2003, Identifying key factors affecting consumer purchase behavior in an online shopping context, International Journal Of Retail \& Distribution Management, Vol.31, No.1. 
Rasheed, FA \&Abadi MF 2014, Impact of Service Quality, Trust and Perceived Value on Customer Loyalty in Malysia services industries, Procedia-Social and Behavioral Sciences, Vol 164, No. 298-304.

Shartykarini, S, 2016, Pengaruhharga, kualitas produk dan kualitas layanan terhadap kepuasan pelanggan dalam membentuk loyalitas pelanggan (Studipengunjung cafe di Banjarbaru), Vol.4, No.1.

Solimun 2002, Strctural Equation Modeling Lisrel dan Amos, Fakultas MIPA, Universitas Brawijaya, Malang

Tjiptono, F, 2000. Strategi Pemasaran.Yogyakarta: Andi Offset

Walpole, Ronaldo, E 1995, Pengantar Statistika, Edisi ke-3, PT. Gramedia PustakaUtama, Jakarta

Wijayanti, Ari 2008,"Strategi Meningkatkan Loyalitas Melalui Kepuasan Pelanggan (Studi
Kasus ; Produk Kartu Selular Prabayar MentariIndosat Wilayah Semarang)", Tesis, Magister Manajemen, Universitas Diponegoro

Wulandari, NL, Kusuma Negara, IM \&KusumaDewi, LGL 2016, PengaruhKepuasan, Kepercayaan Dan HargaTerhadapLoyalitasWisatawanPenggunaLa yanan Booking. Com, Jurnal IPTA, Vol.4, No.2

\section{Profil penulis}

Rizki Adhani Fadila, Mahasiswa Program Studi Magister Manajemen, Fakultas Ekonomi dan Bisnis,Universitas Lambung Mangkurat. Banjarmasin.

Jl. Brigjen H. Hasan Basri, Pangeran, Kec.

Banjarmasin Utara, Kota Banjarmasin, Kalimantan Selatan 70123, Indonesia

Email : rizky0886@gmail.com 